\title{
Mill on the Primacy of Practical Reason
}

\section{Forthcoming in Analysis}

\section{Christopher Macleod, University of Lancaster}

In this article, I wish to argue that J.S. Mill holds that theoretical reason is subordinate to practical reason. Ultimately, this amounts to the claim that the norms of theoretical reason - those rules governing how we ought to believe - are grounded in considerations of utility. I begin, in section 1 , by offering an outline of Mill's account of 'Art of Life' (the body of rules governing how we should $a c t$ ), before turning in section 2, to Mill's account of the 'Art of Thinking' (the body of rules governing how we should believe). In section 3, I suggest that, for Mill, the Art of Thinking is subordinate to the Art of Life, and that in an important sense, therefore, theoretical reason is subordinate to practical reason.

\section{Mill on the Art of Life}

In System of Logic VI.xii, Mill offers a sketch of his theory of practical reason. Mill sets out his theory by introducing a distinction between what he labels 'science' and 'art'. "Propositions of science assert a matter of fact: an existence, a co-existence, a succession, or a resemblance." In contrast, statements of art are "expressed by the words ought or should be". Such statements are "generically different from one[s] which [are] expressed by is, or will be", and "do not assert that any thing is, but enjoin or recommend that something should be" (System, VIII: 949). "[T]he imperative mood is the characteristic of art, as distinguished from science. Whatever speaks in rules, or precepts, not in assertions respecting matters of fact, is art" (System, VIII: 943).

The distinction, of course, is between the normative and the factual, and Mill's use of 'art' and 'science' to identify this difference recurs throughout his work. ${ }^{2}$ A particular useful discussion is provided in On the Definition of Political Economy.

$[\mathrm{I}]$ deas of science and art [...] differ from one another as the understanding differs from the will, or as the indicative mood in grammar differs from the imperative. The one deals in facts, the other in precepts. Science is a collection of truths; art, a body of rules, or directions for conduct. The language of science is, This is, or, This is not; This does, or does not, happen. The language of art is, Do this; Avoid that. Science takes cognisance of a phenomenon, and endeavours to discover its law; art proposes to itself an end, and looks out for means to effect it. (Definition, IV: 312)

\footnotetext{
${ }^{1}$ All quotes from Mill are taken from Mill (1963-91) and are given by (short title, volume: page).

${ }^{2}$ See Macleod (2013) for a fuller discussion of Mill on the art/science divide.
} 
All arts, Mill claims, are derived from the assumption that some object or state of affairs is valuable. "Every art has one first principle, or general major premise, not borrowed from science; that which enunciates the object aimed at, and affirms it to be a desirable object" (System, VIII: 949). "The art proposes to itself an end to be attained, defines the end, and hands it over to the science. The science receives it, considers it as a phenomenon or effect to be studied, and having investigated its causes and conditions, sends it back to art with a theorem of the combination of circumstances by which it could be produced" (System, VIII: 944). Each art is therefore formulated as an autonomous action-guiding body of rules, informed by a scientific understanding of the world, designed to bring about a specified end considered desirable: "[a]n art, or a body of art, consists of the rules, together with as much of the speculative propositions as comprises the justification of those rules" (System, VIII: 947). Mill offers the examples of "architecture" and the "medical arts". Architecture is the body of rules which aims at "beautiful or imposing" buildings; medicine is the body of rules which aims at the "preservation of health" (System, VIII: 949).

We might term the ends of the individual arts proximate ends. Such ends, Mill notes, are not self-certifying, and can often come into conflict. The job of justifying and reconciling the ends set by the various arts - discerning their "place in the scale of desirable things", and determining what we should do, all things considered - is given to what he terms the "Art of Life" or "Practical Reason" (System, VIII: 949-50). Such determinations can, Mill claims, only take place on the basis of "an ultimate standard, or first principle of Teleology [...] a Philosophia Prima peculiar to Art [...] some standard by which to determine the goodness or badness, absolute and comparative, of ends or objects of desire" (System, VIII: 951).

Each art, then, sets a proximate end which is itself justified by the overarching final end. That ultimate end is, Mill claims, happiness.

[T] he general principle to which all rules of practice ought to conform, and the test by which they should be tried, is that of conduciveness to the happiness of mankind, or rather, of all sentient beings: in other words, that the promotion of happiness is the ultimate principle of Teleology. (System, VIII: 951)

Mill directs the reader to "the little volume entitled Utilitarianism" for "an express discussion and vindication of this principle" (System, VIII: 951). A picture therefore emerges of happiness as grounding practical reason, or the Art of Life, as a whole. "I do not mean to assert that the promotion of happiness should be itself the end of all actions, or even of all rules of action. It is the justification, and ought to be the controller, of all ends, but is not itself the sole end" (System, VIII: 952). ${ }^{3}$

\footnotetext{
${ }^{3}$ It is, we might note, from happiness as the grounds of practical reason that Mill derives happiness as the grounds of morality - and not the reverse. When Mill argues for the principle of utility, he does so from the standpoint of practicality as a whole, appealing to what we find a desirable end of action simpliciter - not
} 


\section{Mill on the Art of Thinking}

Mill has, on occasion, been charged with psychologism about logic - the view, roughly, that the laws of logic are simply descriptive psychological laws. ${ }^{4}$ The charge, at least in the simple sense of attempting to reduce the question of how we should (as a matter of logic) reason to a question of how we $d o$ (as a matter of psychology) reason, cannot be sustained. For Mill is finely attuned to normativity of logic - and is clearly aware that, because of its normative status, it cannot be regarded merely as science. ${ }^{5}$

Chapter 20 of the Examination of Sir William Hamilton's Philosophy deals with the question of whether logic is a science or an art. Mill's foil throughout the chapter is William Hamilton's own account of logic as the "Science of the Laws of Thought as Thought" (Examination, IX: 348). Mill's criticism of this formulation is detailed, and convincing - but for the purposes here, it will be enough to note that he ultimately argues that Hamilton is inconsistent. Hamilton claims that logic is a science, but as Mill observes, we can only understand logic as the study of "the form of thought as thought" insofar as thought as thought is interpreted to mean valid thought. To the extent that logic is the study of valid thought, however, it is not treated as a science, but rather as an

Art - that of a mere system of rules. It leaves Science to Psychology, and represents Logic as merely offering to thinkers a collection of precepts, which they are enjoined to observe, not in order that they may think, but that they may think correctly, or validly.

This conception of logic of as an art, which Hamilton adopts in practice, Mill claims, "is much nearer the mark" than Hamilton's professed view of logic as a science. The study of thought as a science is merely the study of psychology, and not of logic - "the fact of thinking is a psychological phaenomenon and Logic is a different thing from Psychology" (Examination, IX: 357). Logic, in the sense of being the discipline concerning the rules of valid inference, is "the Art of Thinking, which means of correct thinking" (Examination, IX: 361).

In this sense, Mill clearly regards logic as an art. Or at least logic includes, as a significant part, this art - for Mill goes on to clarify that logic is not only the Art of Thinking, but also the "science of the conditions of correct thinking" (Examination, IX: 361). Indeed, this understanding of logic as involving art and science is confirmed by the System of Logic, where the logic is suggested to

merely from the moral point of view - and then moving to argue that this end must thereby be the ultimate end of morality. "[H]appiness is the sole end of human action, and the promotion of it the test by which to judge of all human conduct; from whence it necessarily follows that it must be the criterion of morality, since a part is included in the whole" (Utilitarianism, X: 237, my emphasis). See Eggleston, Miller, and Weinstein (2010) for useful discussion.

${ }^{4}$ See Skorupski (1989: 164ff.) for a useful discussion of the history of the charge.

${ }^{5}$ Cf. Godden (2017: 175-7). 
be "the art and science of the pursuit of truth" (System, VII: 4-5). The reason, likely, that Mill thinks it convenient to fold the descriptive science of thought into a definition of logic, is that scientific propositions about our mental operations and the world need to be drawn upon to frame satisfactory rules of thought for art. "[A]rt, or a body of art," we might remember, "consists of the rules, together with as much of the speculative propositions as comprises the justification of those rules" (System, VIII: 947, my emphasis).

Whether we choose to think of logic as the Art of Thinking, with corollary facts of science, or as the Art of Thinking united with a corresponding science, however, is mainly a terminological question. Wherever the boundaries of logic, properly so-called, lie, it is clear that Mill thinks that there is an art which is made up of a body of rules corresponding to the norms of good inference: "a set of rules or canons for testing the sufficiency of any given evidence to prove any given proposition" (System, VIII: 10-1). Such rules - the principle of enumerative induction, and the clarification of that principle provided by the Canons of Induction which form the basis of scientific enquiry $^{6}$ - provide guidance on how to reason well. And, as is the case in all arts, the rules of this art must be rules framed in reference to some end, which is taken to be valuable. That end, Mill claims, is truth.

[W]hat is, peculiarly and emphatically, the end of Thinking? Surely it is the attainment of Truth. [...] The most important, then, and at bottom the only important quality of a thought being its truth, the laws or precepts provided for the guidance of thought must surely have for their principal purpose that the products of thinking shall be true. (Examination, IX: 365)

That Mill identifies truth as the end of logic, of course, points to a significant difference between his conception of that subject and that which has become dominant in twenty-first century philosophy. Mill thinks of logic not as merely concerned with deductive inferences, but with all arguments that are capable of eliciting new knowledge - theoretical reason, in all of its aspects. Mill's interest, in his terms, is in the "Logic of Truth", and not merely the "Logic of Consistency" (System, VII: 208).

\section{The Relation of Truth and Utility}

In System of Logic VI.xii.6, Mill notes that "[t]here is, then, a Philosophia Prima peculiar to Art, as there is one which belongs to Science. There are not only first principles of Knowledge, but first principles of Conduct" (System, VIII: 951). Mill's reference to the Philosophia Prima of Science the first principle of Knowledge - coming at the end of a book-long treatment of the topic is, of

\footnotetext{
${ }^{6}$ See Fumerton (2009: 168-73) for detailed discussion of these rules.
} 
course, to the principle of enumerative induction. ${ }^{7}$ Because he presents the contrast in this way, the assumption has been that Mill holds that there is a theoretical principle which is the mirror image of the principle of utility - a fundamental theoretical norm governing what we have reason to believe, in much the same way as the principle of utility sits as the fundamental practical norm governing how we have reason to act. ${ }^{8}$ Mill's conception of reason, under this picture, is seen as bicameral. ${ }^{9}$

The reality is, however, that although Mill notes that there is a first principle in each domain of reason, he nowhere explicitly commits himself to this model of the jurisdiction of, and relation between, those domains. And, indeed, there is good reason to doubt that theoretical and practical reason exhibit this kind of symmetry. For if how we should believe is a question of the Art of Thinking, and if, as Mill claims in System VI.xii.6, "all other arts are subordinate" to the Art of Life, then it seems quite clear that the Art of Thinking must be subordinate to the Art of Life (System, VIII: 951). Because Mill treats the Art of Life not simply as the most general practical art, but also as the most general art simpliciter, we must take its scope to include all human activity that is subject to normative assessment - including our thinking.

As such, theoretical reason - that aspect of reason which determines how we should believe must be taken to fall under the scope of practical reason, rather than to sit alongside it. This order of priority is confirmed by a passage in Grote's Plato, during which Mill refers to "an art which is a main portion of the Art of Living - that of not believing except on sufficient evidence" (Grote's Plato, XI: 405). Again, the art guiding how we should believe is viewed as part of the broader art of how we should live. It is this broader art which must determine whether the "aim of any particular art is worthy and desirable, and what is its place in the scale of desirable things" (System, VIII: 949) and truth, as the end of the Art of Thinking, should not be thought to be an exception. The end of truth for belief, after all, is not given to us a priori - nor could it be, according to Mill's empiricism, unless it is trivially verbal that we ought to believe what is true. As such the end of truth cannot be taken to be self-certifying.

We should be clear about what is, and what is not, involved in the claim that the Art of Thinking falls under the Art of Life. The claim is of course not that Mill abandons truth as the appropriate end of thinking and believing. "The most important quality of an opinion on any momentous subject is its truth or falsity, which to us resolves itself into the sufficiency of the evidence on which it rests" (Theism, X: 430). It concerns, rather, the justification that Mill thinks can be offered for taking it as such an end. If the Art of Thinking falls under the Art of Life, that

\footnotetext{
${ }^{7}$ We should not be misled by Mill's reference to this first principle of science into thinking that this principle will itself belong to science. As a principle, or a rule as to what we should believe, it will itself be a proposition of art: the normative claim that that having observed that $x_{1}, x_{2}, x_{3}, \ldots x_{\mathrm{n}}$ are $P$, one should believe that $x_{\mathrm{n}+1}$ is $P$. ${ }^{8}$ Such a view, of course, bears comparison to recent work - a product of the 'value turn' in epistemology which seeks to draw parallels between the 'oughts' of epistemology and ethics. See, for instance, M. Steup (1988) and Berker (2013). More broadly, of course, it also connects the tradition considering the "ethics of belief'. See Clifford (1876).

${ }^{9}$ Indeed, in previous work, it has been my own position. See Macleod (2014: 151-5).
} 
justification will be, at its roots, a practical one: a concern for utility. But that should not be taken to in any way alter the proximate end of belief, and we should not think that Mill takes that end any less seriously than one who thinks of it as self-grounding. That the art of architecture is ultimately justified by concerns of utility, after all, does not mean that Mill thinks beautiful or imposing buildings any less important. Nor does it mean that Mill thinks that we ought, while engaged in architectural work, to aim directly at utility, rather than taking the construction of beautiful or imposing buildings as our guiding end.

The claim that the proximate end of truth is justified ultimately by the final end of utility, then, is certainly not that we should simply believe whatever makes us happy. But it of course it does depend on the claim that truth is in general conducive to utility. This is a claim, however, which Mill quite clearly endorses. When engaging with the argument that some true opinions might justifiably be silenced on the grounds that they could be something other than conducive to utility, Mill explicitly denies that possibility. "The truth of an opinion is part of its utility" (Liberty, XVIII: 233). "The knowledge of every positive truth is a useful acquisition" (Utility of Religion, X: 405). Possession of the truth is, Mill thinks, itself a useful means to happiness. ${ }^{10}$

Of course, any account that seeks to ground the normative force of truth on that of utility must contend with the manifest psychological reality that truth is generally taken to be not only a means to happiness, but also as an appropriate end in itself. In this regard, however, we might draw a telling comparison to the end of virtue. As is well known, Mill holds that the end of virtue, though grounded in utility and itself a proximate end in axiological terms, comes, nevertheless, to be "desired disinterestedly, for itself" (Utilitarianism, X: 235). It does so by process of association with utility.

There was no original desire of [virtue], or motive to it, save its conduciveness to pleasure, and especially to protection from pain. But through the association thus formed, it may be felt a good in itself, and desired as such with as great intensity as any other good. (Utilitarianism, $\mathrm{X}: 236)$

Virtue and utility come to be so closely associated, Mill holds, that virtue is seen as "a good in itself, without looking to any end beyond it" and "a thing desirable in itself, even although, in the individual instance, it should not produce those other desirable consequences which it tends to produce" (Utilitarianism, X: 235). ${ }^{11}$ And indeed, one can see, in broad outline, how a similar process could lead to our viewing truth as a desirable end in itself. In order, on any given occasion, to secure happiness or protection from pain, one must have some true belief as to the means of achieving that

\footnotetext{
${ }^{10}$ Mill, of course, need not maintain that belief in truth is on each and every occasion conducive to utility - but rather that the connection between possessing truth and achieving utility is strong enough to justify its standing as a human end.

${ }^{11}$ See Miller (2010: 41-3) and Crisp (1997: 83-6) for useful reconstructions of Mill's account of virtue.
} 
end. On many occasions we experience utility, then, some true belief must serve as prerequisite for that experience - and holding true beliefs will, over time, become more and more closely associated with utility, and be thought of as an end in itself.

Truth, then, functions as a genuine end for the Art of Thinking - and one that comes to be thought of not merely as a means to utility. For all normal purposes, Mill holds, our thought should be guided by considerations of truth, and as such we should form beliefs strictly according to the norms of scientific enquiry. Because of this relative independence of theoretical reason, it is perhaps not surprising that Mill makes relatively little play of the fact that theoretical reason is ultimately answerable to considerations of utility: in the vast majority of instances, the question simply does not arise as to whether practical reason should have any role in this process. ${ }^{12}$

\section{Conclusion}

I have, in this article, suggested that there is an important sense in which Mill holds that theoretical reason is subordinate to practical reason. In short, how we should believe is governed by the Art of Thinking, which provides rules of theoretical reasoning that have truth as their end - and given Mill's claim that all arts are subordinate to the Art of Life, it seems clear that the Art of Thinking must be taken to fall under the Art of Life, which is to say "Practical Reason" (System, VIII: 950). This has been missed by Mill scholars, I think, because until recently relatively little attention has been paid to the structure of the Art of Life - and almost no attention to the normative dimension of Mill's theory of knowledge, which casts good formation of belief as an art. As these aspects of Mill's philosophy become better understood, so too will the relationship between theoretical and practical reason in his work.

That Mill holds that practical reason is primary should, I think, strike us as interesting in itself. But it should also strike us as interesting because it provides further insight into Mill's relation to later movements in philosophy. It has recently been argued that Mill's antirealist approach to normativity pushes him in the direction of later pragmatist movements by leading him to view norms of theoretical and practical reason as, in the final analysis, tools to help us navigate the world. ${ }^{13}$ The

\footnotetext{
${ }^{12}$ One qualification is perhaps significant enough to be worthy of notice. Where theoretical reason remains silent on any given proposition, Mill holds that we cannot be warranted in believing that proposition. But practical reason can legitimately play some role in regulating our thought in these cases, warranting hope: "it appears to me that the indulgence of hope with regard to the government of the universe and the destiny of man after death, while we recognize as a clear truth that we have no ground for more than a hope, is legitimate and philosophically defensible. The beneficial effect of such a hope is far from trifling. It makes life and human nature a far greater thing to the feelings, and gives greater strength as well as greater solemnity to all the sentiments which are awakened in us by our fellow-creatures and by mankind at large" (Theism, X: 485). To the extent that hope is, in part, a cognitive state, then, Mill clearly does see practical reason playing a role in informing how we think about the world.

${ }^{13}$ See Macleod (2016: 78). As I suggest in that paper, this connection is hardly surprising. Alexander Bain, a key figure in the emergence of pragmatism was himself a disciple of Mill; William James claimed to have "first learned the pragmatic openness of mind" from Mill, who he pictured "as our leader were he alive to-day" (James 1907: v). The connection merits more attention than it has yet received in the secondary literature.
} 
claim that theoretical reason at some level has its foundation in our practical interests - and that truth is desirable because of its use to us as human beings - is of course another such push towards pragmatism, and a significant one. 


\section{Bibliography}

Berker, C. 2013. "Epistemic Teleology and the Separateness of Propositions," Philosophical Review 122(3): $337-93$.

Clifford, W.J. 1876. "The Ethics of Belief," Contemporary Review 29: 289-309.

Crisp, R. 1997. Mill's Utilitarianism. London: Routledge.

Eggleston, B., Miller, D., Weinstein, D. 2010. "Introduction” in B. Eggleston, D.E. Miller, D. Weinstein (eds.) John Stuart Mill and The Art of Life. New York, NY: Oxford University Press, 2010.

Fumerton, R. 2009. “Mill's Logic, Metaphysics, and Epistemology,” in W. Donner and R. Fumerton Mill. Malden, MA: Wiley-Blackwell.

Godden, D. 2017. "Mill on Logic," in C. Macleod and D.E. Miller (eds.) A Companion to Mill. Oxford: WileyBlackwell.

James, W. 1907. Pragmatism. New York: Longmans, Green and Co.

Macleod, C. 2013. “Was Mill a Non-Cognitivist?” Southern Journal of Philosophy 51(2): 206-23.

Macleod, C. 2014. "Mill on the Epistemology of Reasons: A Comparison with Kant," in A. Loizides (ed.) Mill's System of Logic: Critical Appraisals. New York, NY: Routledge.

Macleod, C. 2016. “Mill's Antirealism,” Philosophical Quarterly (2016) 66(263): 261-79.

Mill, J.S. 1963-91. The Collected Works of John Stuart Mill, 33 vols., under the general editorship of John M.

Robson. Toronto: University of Toronto Press; London: Routledge.

Miller, D. 2010. J.S. Mill. Malden, MA: Polity Press.

Steup, M. 1988. “The Deontic Conception of Epistemic Justification,” Philosophical Studies 53(1): 65-84.

Skorupski, J. John Stuart Mill. London: Routledge, 1989. 